\title{
Models Applied Upbringing Children of Upper Nobility of the Grand Duchy of Lithuania in the 16th - the Middle of the 17 th Centuries
}

\author{
Raimonda Ragauskienè \\ Lithuanian University of Educational Sciences, Faculty of History, Department of Lithuanian History, \\ T. Ševčenkos St. 31, LT-03111 Vilnius, Lithuania, raimonda.ragauskiene@leu.lt
}

Abstract. On the basis of historiography and new historical sources, the article analyses models applied upbringing children of upper nobility in the Grand Duchy of Lithuania in the 16th c. - the middle of the 17th c. The general and individual factors characteristic of the upper nobility of GDL, which predetermined upbringing of the children from the target social stratum, are discussed. Attempts are made to identify how early socialisation of girls and boys occurred as well as to discuss teaching of elder children (girls and boys) of upper nobility including the content of their teaching.

Keywords: the Grand Duchy of Lithuania, the 16-17th centuries, child, childhood socialisation, models of upbringing, education in the period of GDL.

\section{Introduction}

Over all historic periods children have been an integral part of society. To enable a child to take part in public life and to perform certain social roles, socialisation is needed. During this process social norms and values are internalised and a specific sense of identity of self-awareness is acquired (Giddens, p. 41). In other words, a child enters society and learns to perform certain roles. Issues of child's socialisation (upbringing and education) in the Grand Duchy of Lithuania (hereinafter - GDL, Lithuania), as well as the themes 
of child and childhood during this period in historiography has not developed into an autonomous sphere of research. Broader synthesis has not been conducted and works focusing on separate problems have not been available. Meilè Lukšienė is considered to be one of the pioneers of such research in Lithuania, who together with co-authors published the work 'Lietuvos mokyklos ir pedagoginès minties istorijos bruožai' (Features of History of School and Pedagogical Thought in Lithuania) in 1983, which may be regarded as synthesis. This work analyses the development of a pedagogical thought in the second half of the 18th c. - the middle of the 19th c. (Karčiauskiené, Lukšiene and others). A certain breakthrough in research on history of old education was observed in the last decade of the 20th century. Following the previous research of Jerzy Ochmańsky (1972; 1996), a number of significant publications by Edvardas Gudavičius, Zigmantas Kiaupa, which discussed the emergence of schools in Lithuania, the first schools in separate regions and level of training in them were issued (Gudavičius, 1994; Kiaupa, 1998). Later this experience was generalised by Arvydas Pacevičius (2001). The beginning of announcing early sources of education history (Lietuvos mokykla ir pedagogine mintis XIII-XVII a. (School and Pedagogical Thought in the 13-17th c.) Istorijos šaltinių antologija (Anthology of Historical Sources), Lietuvos pedagogines minties raida XVI-XVII a. kultūros veikejuz raštuose (Development of Lithuanian Pedagogical Thought in the Works by the Cultural Players of the 16-17th c.) was made. The studies of the education reform, which was launched in GDL in the 18th c., were carried out (Račkauskas, 1994). New details in the history of the old pedagogy were revealed conducting research on reformation in GDL. The foundations were laid for establishment of network of protestant schools in Lithuania and contribution of separate nobility representatives to development of the educational system in Lithuania were identified (Lukšaite, 1999). Hence, the beginning was made establishing the network of schools in old Lithuania, the level of training in them as well as identifying the attitude of separate public figures, educators and teachers towards upbringing issues.

It is obvious that seeking a broader picture of history of education, interdisciplinary studies are needed, which would employ the comparative analysis of science, religion, mentality, literature and others (Classen, 2005). Namely the new Lithuanian historiography on issues of education in the period of GDL already offers a choice of more modern themes (Sarcevičienè, 2003), such as the oldest children's toys and games (Blaževičius, 2011) or children's toys and games in the 19 c. - the beginning of the 20th c. (Pliuraite-Andrejeviene, 2012). The children are noticed in the studies, which are not directly linked to children: in critical art works on clothing or portraiture, conducting research on clientele relations (Matušakaité, 2003, p. 104-108 etc.; Ragauskiene, 2003), etc. However, such studies are still few. The monograph by Olga Mastianica (2012), which focuses on slightly later experience in education (the 19th century), is ascribed to works of bigger volume. The author carried out research on changing attitude of society towards women's education, goals and objectives imposed on it and importance of such education. 
The bigger contribution of Polish historians to issues of education in the period of GDL should be singled out. It is important to mention the synthetic works by Dorota Żołądź-Strzelczyk (2002; 2012) and Katarzyna Kabacińskos-Łuczak (2007) and other authors (Lewińska, 1995; Od narodzin do wieku dojrzałego. Dzieci i młodziez w Polsce, 2002; Dawne i współczesne zabawki dziecięce, 2010), which targeted at child's history in the old Poland and allocated specific attention to child's upbringing. Polish historians frequently use Lithuanian materials but incorrectly make conclusions about experience in the old Poland: for example, experience of GDL nobility, such as the Radvilos, the Chodkevičiai, is presented as issues of history of education and childhood in the old Poland rather than those of GDL. The works by Polish historians, who carried out research on education of children from the most distinguished GDL upper nobility families (e.g., the Radvilos: both branches of Catholics and Protestants) or on studies of elder offsprings of the Radvilos in foreign universities are of not less significance to Lithuanian experience. A number of more significant works by Henryk Wisner (1969), Urszula Augustyniak (1999) should be mentioned as well as the research by Marian Chachaj (1995), which discussed a broader range of literature on university studies of the Radvilos.

The goal of the research: the article aims to present an overview of models of upbringing applied upbringing children of the upper nobility of GDL and their socialisation up to 14-16 years in the 16-17th centuries. It does not make attempts to present an exhaustive analysis of the issue but is targeted at discussion of separate features of upbringing and models of socialisation based on gender issues. According to the Third Statute of Lithuania, a 14 year old girl was considered to be adult and was entitled to marriage, whereas a young man acquired this status at the age of 18. Hence, upbringing of young men lasted until they reached the age of 18 . However, the tradition to send 14-16 year old boys to studies in Western Europe prevailed in GDL in the studied period. Since the process of socialisation of those young people was different from the perspective of quality, it is not analysed in this article. The objectives of the research: 1) to analyse factors, which determined upbringing of children of upper nobility; 2) to discuss peculiarities of early socialisation (up to 7 years old) of children of upper nobility; and 3) to discuss separate features of later socialisation of children of upper nobility (from 7 to 14-16 years), issues related to parents' attitude towards education. The choice of the group of upper nobility in GDL of the 16th c. - the middle of the 17th c. was determined by abundance of sources. The knowledge of upbringing of lower strata of the society of the aforesaid period is very limited and this is also related to the fact that the majority of representatives of these social layers were illiterate. The research methods: theoretical - analysis of historiography on issues of upbringing of children of upper nobility in GDL and analysis of new historic sources newly available to researchers, descriptive method. 


\section{Factors, which determined upbringing of upper nobility children}

Child's upbringing in GDL in the 16th c. - the middle of the 17th c., similar to the rest of Europe, to biggest extent depended on social status of the family. The researchers noticed long time ago that the length of childhood was different to children of peasants, townspeople and nobility just as the status of these social strata. Children's toys were also related to socio-cultural environment (Pliuraité-Andrejeviené, 2012, p. 25). A child was approached in one way by peasants or town people, whereas in the families of nobility and upper nobility, in particular, attitudes towards child were totally different. For example in the countryside, every pair of hands mattered in agricultural activities. Therefore, slightly elder children, who were already able to take part in household activities, were immediately introduced into the world of adults. Their childhood was shortened to maximum and lasted as long as a child was dependent on assistance and care. Only a very small minority of peasants' children would acquire elementary primary education in the parish school, i.e., would obtain basics of religion and the primer skills of grammar. In one of the first schools, which was opened in the Naujamiestis Manor (Powiat of Upytè) by evangelist Eustachijus Valavičius in 1583, it was obligatory "to learn prayers and confession of faith as well as 10 commandments of God" (The regulations on school to peasants of Naujamiestis Manor by E. Valavičius in 1583) (Lietuvos mokykla ir pedagogine mintis XIII-XVII a., p. 158). Differently from separate Western European countries, such as Denmark, which started implementing the idea of obligatory primary education as early as the 17 th c., children of GDL peasants and the majority of children in towns remained illiterate. Neither parents were eager to let their children attend schools, nor sufficient financial recourses were available for maintenance of primary schools. For example, the nobility of Stakliškes applied to the governor with a request to establish a primary school in Stakliškes in the 17th c. However, no such institution was established then and the situation did not change even one hundred years later. The act of visit in 1782 states that though the bishop of Vilnius had ordered, the parish school in Stakliškès had not been built and nothing was heard about daraktorius (a local teacher). The attitude of the local people towards education also changed and in the second half of the 18th c. the peasants in the parish did not express their wish to teach their children. "Ordinary people overloaded with work by the nobles cannot afford sending their children to school, whereas lower rank nobles, who are better off, hire Bachelors and have them in their homes" (Vyskupo Ignoto Jokūbo Masalskio Kauno dekanato vizitacija 1782 m., 2001, p. 143). Though the parson hired daraktorius for two years, the latter was fired because there were no students wiling to learn. Similar situation was observed in other places in Lithuania. If in the whole deanery of Kaunas there were 211 children attending schools in 1781, the number of baptised children was two times bigger in separate parishes (14). 
Thus, the children of the GDL nobility were exposed to best training opportunities and longest lasting childhood.

Upbringing and training of the upper nobility children were predetermined by a big number of individual as well as general features characteristic of the whole social group. The status of a specific family, parents' achievements in the public life, posts taken, possessions and parents' attitude towards learning were of utmost importance. The officials in highest posts in the country, i.e., the nobles, who belonged to the Lithuanian Council of Lords or the Senate, endeavoured to provide their children with education of the highest level. On the other hand, even the daughters in the families of lower rank nobility were not always able to write. For example, Zofija Zborovska, daughter of Gniezno castellan, who got married in Lithuania from Poland in the beginning of the 17th century, was illiterate. After her marriage with Trakai castellan Jurgis Radvila in 1600, due to her mother's illness, she spent some time with her after the wedding and dictated very nostalgic letters to her husband. In her letter of 31 December 1602 to her husband Z. Radvilienè mentioned that she would have written to her husband herself but was not able even to write one letter as her mother wanted her only to learn to read a little bit. Since J. Radvila had studied in Western Europe, his wife had to gear up. Several years later, the same Z. Radviliene managed to sign the letter to her husband she had dictated (3).

The religious factor and the gender of a child also played a significant role. So far no in-depth studies have been carried out into education of the upper nobility from different religious confessions (Catholics, Protestants and Orthodoxies). However it is clear that the content of religious study subjects, in particular, was different. Undoubtedly, a more considerable attention was allotted to upbringing and development of boys compared to girls. The age of a child was also relevant. As it has already been mentioned, in the Third Statute of Lithuania a 14 year old girl was considered to be adult and a young man acquired this status at the age of 18. Hence, upbringing of young men could have theoretically lasted from 14 to 18 years old. In fact, a nobleman or noblewoman may have been considered adults or independent from the others only after getting married. Therefore, for example, after the death of childless Petras Hlebavičius in 1599, his two sisters Marina and Kotryna Hlebovičaitès, who were adult but single at that time yet, did not have the right to take over and manage brother's possessions after his death. They addressed their nephew Jurgis Radvila, son of their deceased sister Elena Hlebovičaite and Nowogrudek palatine Mikalojus Radvila. He became the trustee of his aunts and took over part of possessions pledging to maintain the aunts according to their status. The sisters got married in the same year (1599) (Marina married Fabijonas Jokūbavičius Piaseckis, a landlord in Ašmena Powiat, whereas Kotryna's husband was duke Elijus Giedraitis) $(10 ; 11,1.5)$. This was a short-term trust. The first stage of upbringing of child from the upper nobility stratum began with the birth and lasted until 7 years old. On the basis of the same provisions of the Lithuanian Statute (and this custom was valid during 
the First Statute), a child and a daughter, in particular, had to be under mother's custody until 7 years of age (Ragauskienè, 2003, p. 32).

Thus, the process of education of upper nobility children of GDL in the 16th c. - the 17 th c. was implemented individually as no unified education model was available at that time. The following of European models of elite children education (German, French) may be singled out as a more general tendency observed among the majority of representatives of upper nobility (Augustyniak, 1999, p. 82-83).

\section{Early socialisation of children of upper nobility (up to 7 years)}

Birth of a boy and a girl was met equally joyfully and birth of successor of the family was a serious occasion. When in 1520 a son was born to the Polish king and Lithuanian Grand Duke Sigismund I the Old wrote to his wife: "This double and immeasurable happiness arrived together with the letter of Your Kindness and announced successful childbirth of the sweetest son, who was born with the help of God and is an eternal token of our mutual love. We kindly thank Your Kindness for such a happy and joyful piece of news and insist on your care of your health. Our beloved son will be given the name of Žygimantas, which will be carried by us both" (Acta Tomiciana, 1855, p. 294). On the other hand, birth of a daughter meant certain extinction of the family and marriage of a daughter resulted in "leakage" of some fortune from the family. Despite all the aforesaid, birth of a daughter was also a joyful event. In 1667, when Liudvika Karolina, the last offspring of the Radvilos of Biržai was born, his father Boguslovas Radvila marked this occasion by thundering cannons in Karaliaučius (7). Parents also grieved for all the children, who passed away early. It is enough to read several laments written by Jan Kochanowsk, the famous Polish poet, (2001) after the death of his beloved daughter Ursula ( 2.5 years old) to understand what huge sorrow parents went through.

Theologists, lawyers and teachers, who made attempts to solve issues of upbringing, agreed that the biggest responsibility while preparing children for life was firstly assumed by the family and mothers, in particular, and only then school. Mikalojus Rejus, who exalted marriage in the middle of the 16th c., argued that mothers have to feed and bring up own children (Bogucka, 2009, p. 19). The sources of the second half of the 16th c. - the first half of the 17th c. allow to conclude that upper noblewomen breast-fed their babies themselves. Only when they were not able to do it, noblewomen, for example, Elžbieta Sapiegiene, the wife of GDL Chancellor, had to find a nursing mother for her first-born daughter Ona in 1603 (9). The importance of the role of the mother was emphasised by a number of creators of fugitive literature. According to the author of the funeral speech in 1640, "the real glory is not to be mother and to give birth to children but to bring them up properly and to implant the fear and love of God into them". Such practice was observed in life if the mother did not die right after the childbirth. In 1581 Jonas, son 
of betrayer Grigalius Astikas, unwilling to lose dominions, explained in the court that "his father separated his mother and him from himself in early childhood and he was educated separately". In fact, the judges took into consideration such an explanation and adopted a decision favourable to young Astikas (Ragauskiené, 2003, p. 36).

If a child lost his or her mother in infantry or early childhood, $s$ / he was taken care of by courtiers, nannies, teachers and others appointed by the father. However, the farther himself would attentively enquire about his child and would attend him of her whenever he was able to. In the beginning of the 17th c., in some families of upper nobility of GDL, e.g., in the family of Kristupas II Radvila, Grand Hetman of GDL, there emerged a tradition to establish a separate manor for noble children to prevent dissemination of infectious diseases. Children were taken away from their mothers and placed under direct care of courtiers. However, even in such cases, mothers would communicate with their young children and attend them every day and would reside in the same manor as children.

In more ordinary families young sons and daughters were looked after by mother herself as well as by nannies and courtiers. For example, in the 16th c. the sons of Mikalojus Radvila the Red were brought up by Ana Chomecka, who was presented the Astrava Manor in 1548 for her services. Nine children of Vilnius palatine Radvila the Black were reared by the wife of Stanislovas Piekarskas, the marshal of the noblewoman's manor. At the end of the 16th c. young children of Kristupas Radvila Perkūnas were looked after by Zofija Rotundienè, the wife of Vilnius prefect, and later by Kielčevska, of her son-inlaw, royal secretary Kristupas Dzierzek (1; Ragauskiené, 2002, p. 152, 377). The available correspondence of upper nobility evidences strong emotions of parents, their link with children and love to them. The youngest children were addressed by diminutive names (Anuška, Basia, Kristupèlis, Michnikas, Zoska, Jonušèlis or Halčuchna). The main themes prevailing in the letters of the upper nobles to their husbands or mothers included issues of children's health, appropriate clothing, food and similar. For example, when Mikalojus Kristupas Radvila Našlaitèlis was born in 1549, the father, having received a joyful piece of news about the birth of son, in his letter asked his wife if the son was handsome and whom he resembled of. Answering the letter his wife Elžbieta Šidlovecka Radvilienè left the right to decide to the husband himself and only asked to send honey and a special cover to protect their son from flies. When junior Radvila reached the age of two years old and daughter Elžbieta was born, E. Radviliené sent messages to her mother about pranks of her grandchildren. Her son, who was tenderly called Kristupèlis by his mother, according to her, "is healthy by the grace of God, only covered in sports, especially his legs because he always runs barefooted". While playing, the boy liked to pretend of his sister and when asked where he himself was at that moment, used to say that "he had left for madam grandmother's" (Ragauskienè, Ragauskas, 2002, p. 97-100). Kotryna Tenčinska Radvilienè used to spend most of the time with her children Elžbieta, Kristupas and her stepson Jonušas until they reached the age of 7 . This can be concluded from her letters to her husband K. Radvila Perkūnas (5). Similar situation was observed in the families 
of Sapiegos or Chodkevičiai in the beginning of the 17th century. For example, writing about her little sons Mikalojus and Kristupas, their mother E. Sapiegienè sent wishes on behalf of the boys because "those two are so small that they cannot even speak yet" (8, p. 242). It should be pointed out that mother's place was very important developing linguistic skills of young daughters or sons. The correspondence between Jonas Karolis Chodkevičius, Grand Hetman of GDL, and his wife was also about the matters of children (4). Actually, moralists of that period, e.g., Augustinas Lavskis (1614), reprehended unconditional love of parents (mothers in particular) to their children. It was compared to "pure disease and enervating fever" (Sarcevičienè, 2003, p. 6). Parents were expected to be active participants in formation of child's character and users of strict hand policy.

In their early age boys and girls were reared together. At the same time, the division between models of upbringing at the analysed period was implemented mainly through giving toys, which were related to different functions of genders in society and through organising of children's games. Teachers firstly and most frequently prioritised moral education of children, which was understood as religious (development of deep belief) and civic (devotion to the Motherland) upbringing and teaching of customs. Thus, a considerable attention was allocated to religious upbringing of young children, who were taught faith, piety and submission. They were also shown examples of appropriate people because Erazmas Gličneris, who worked in the Manor of Dukes Slutskiai and was the author of the first pedagogical tractate published in Poland in 1558, equalled a child to a monkey, who wants to imitate everything what $\mathrm{s} /$ he sees.

Children's health was a very serious issue. Young children were taught elementary hygiene skills. Mothers and fathers either taught their children some manners (e.g. table manners) or gave instructions to children's nannies. For example, in the beginning of the 17th century young daughters of Vilnius castellan Jonušas Radvila would have breakfast together with their parents but the girls were taken care of not to "get dirty like piglets". GDL stable administrator Boguslovas Radvila had given instructions to nannies and servants regarding the diet, clothing, airing of premises and personal hygiene of his daughter Liudvika Karolina. The daughter was served fresh fruit in the morning, her teeth were brushed after meals, it was forbidden to heat premises too much and her underwear had to be changed daily (Augustyniak, 1999).

The upper nobles allocated considerable attention to physical education of their children as well as to various body exercises. Riding a horse was among more important activities even for young boys. For example, Jonušas II Radvila received his first horse as a present at the age of five in 1617. Generally speaking, boys' games contained elements of knightly culture: horses, munition and jousts. The girls were able to enter the adults' life with the help of toys and games. They used to play with dolls made of clay or wood. Some dolls had moving arms or legs and were dressed in expensive clothes. In the 17th c. the multi-storeyed houses for dolls became fashionable (Żołądź-Strzelczyk, Kabacińska-Łuczak, 2012, p. 130-132). 
No preaching was used while upbringing children and the rod was considered to be the main means of upbringing. Aaronas Aleksandras Olizarovijus, the author of the tractate "On Political Union of People" published in 1651, devoted a chapter to children's punishments where he envisaged their benefit but advised to find a certain balance: "punishments should not exceed the breaking itself, whereas parents should be neither too strict to become cruel, nor too forgiving to become irresponsible". Telling lies, stubbornness and anger were the most severely punished offenses. Even being a girl did not prevent from physical punishments (e.g., Liudvika Karolina Radvilaitè) (Olizarovijus, 2003; Augustyniak, 1999, p. 80).

\section{Upbringing tendencies of elder children (7-14 years) of upper nobility}

The content of upbringing of elder children differed due to different attitude towards girls and boys as well as towards their future tasks in society. Adomas Rasijus, a professional teacher, who worked for the Radvilos, expressed his opinion in 1619 that in future "education has to be different for sons and daughters: the first have to be taught science and military subjects, whereas the latter have to be taught piety and subjects of economics" (Lietuvos mokykla ir pedagogine mintis XIII-XVII a., p. 301). His opinion was supported by A. A. Olizarovijus, who pointed out that girls need elementary knowledge of reading, writing and music. They should take up needlework as well. Noble girls should start their teaching at the age of 6 but should be provided only with primary education (Lukšaitè, 1991, p. 72).

Actually daughters of the upper nobility and sometimes lower rank nobility were brought up only at home and were provided with home education. Upper noblewomen used to invite preteen daughters of other upper noblewomen or loyal to them client nobles and educate them together with their own daughters. Hence, relatively large manor schools, which provided primary or slightly higher education, were formed. Thereby, not only Elžbieta Radvilaitè, daughter of the upper noblewoman K. Tenčinska Radviliené, grew up in her manor but also Zofija and Kotryna Radvilaite, young daughter of palatine of Nowogrudek and cousins of Elžbieta had lived there since 1585. After the death of mother, Barbora Zbaražska, a young daughter of Dorota Sapiegienè from her first marriage, a cousin of Radviliené, was admitted to the manor. Young castellan of Vilnius as well s several other young girls could have been reared in the manor of K. Tenčinska Radvilienè.

The level of teaching in such manor school was not low. Moreover, about $80-90 \%$ of GDL upper nobility were literate (Urban, 1986, p. 75). In rare cases, for example, like Liudvika Karolina Radvilaitė, who grew up in Karaliaučius, young girls spoke Latin, German and even French. All the young girls knew the Sacred Scripture very well. As it can be seen from the letter written of protestant K. Radvila Perkūnas in 1587, his 8 year 
old and 7 year old nieces read Postylla Grzegorza z Żarnowca (1580). The girls would definitely receive economic knowledge. On the basis of the available materials from the courts, it can be concluded that noblewomen understood legal issues rather well, they knew articles of the Statute particularly the ones related to their rights. The girls would listen to music, learn to dance and would start riding horse rather early (Ragauskiene, 1999, p. 37). It can be concluded that some mothers interested in healing methods and herbs would pass down their knowledge to their daughters: for example, upper noblewomen Radvilienès and Sapiegienés would correspond with Ana Vazaite (Saar-Kozłowska, 2003), who was well aware of herbs in the beginning of the $17 \mathrm{th} \mathrm{c}$. The education of girls would last until they got married.

The upper nobility imposed higher requirements for education of sons. They were taught at home until 7 years old, where children of lower rank nobles, who were loyal to the upper noblemen, as well as their relatives were also admitted to manor schools. The children of not very affluent noblemen used to attend parish schools and later were sent to schools of higher level, e.g., in Vilnius or Kedainiai. Some upper noblemen, such as K. II Radvila, used to prepare instructions for training of their sons. It should be pointed out that the upper nobility in Lithuania were not so strict in terms of early education of their sons compared to a number of Polish upper noblemen. For example, Polish Chancellor Janas Zamoiskis set out a particularly strict timetable to his son Tomaš: child's lessons would start at $5.30 \mathrm{a} . \mathrm{m}$. and would last until 9 p.m. in the evening. Only Thursday was dedicated to rest (Kowalczyk, 2002). Mothers would also participate in education of their sons. Some of them only assumed responsibility for their health care and nutrition. For example, K. II Radvila allowed his 12 year old son Jonušas II to visit his mother only after lunch and in the evening and to use the rest of time for studies or masculine activities (Jankowski, 1898, p. 49).

More active upper noblewomen, especially after they widowed, used to make decisions alone or asked for some advice from their relative men regarding choice of teachers or schools for their sons. For example, under initiative of Duchess Kotryna Slutskiene, E. Gličneris, the most famous teacher of that time, arrived in the manor of Slutskis. The same Duchess admitted Andrius Koslas, an educator, to the same manor of Slutskis (Скеп'ян, p. 81). Kotryna Goraiska, another upper noblewoman, widow of Užpaliai starosta, took care of university education of her two sons Petras and Kristupas Goraiskiai. In 1620 her son Petras K. Goraiska was sent to Gdansk under initiative of Vilnius castellan Jonušas Radvila, who later was obliged to send Petras to further studies. As she wrote "now I have to take care of studies only of junior son Kristupas" (6).

The upper nobility representatives of GDL practiced a more moderate and varied model of their sons' upbringing. Similar to girls, boys were also required to be able to read the Sacred Scripture, to know the truths of faith and to participate in religious life of the family. Representatives of upper nobility made attempts to make the truths of faith understandable to children, e.g., B. Radvila ordered his preachers not to read too 
long sermons "in order not to suffocate child's wish to listen to sermons" (Augustyniak, 1999, p. 76). Reading and writing was taught to sons of the noble at different age: some started to learn writing being 4-5 years old, whereas the others only at the age of 6 or 7. Attempts were made to provide boys with correspondence skills and they later were taught rhetoric skills. Nobility representative allocated considerable attention to teaching foreign languages to their sons and, therefore, hired foreign servants. However, a certain sense of proportion was observed endeavouring not to overburden children with learning and making attempts to take care of their health. This is clear from a letter written by K. Radvila Perkūnas to Bachelor Lukas Bednarsktas, a teacher of his 12 year old son Jonušas Radvila in 1587, when the latter asked the nobleman to send "Postyllę Grzegorzaną" for Jonušas to read. K. Radvila Perkūnas had left it in Vilnius but remembered that he had given the first part of the Postilla (three books) to nieces, who were together with Jonušas. Therefore, he advised to take these books from the girls and to give to read to the boy. Bachelor was warned not to beat a child, the father forbade teaching his son longer than two hours before the lunch and not more than one hour in the afternoon. It was also requested not to wake the son up in the morning and to wait when the boy wakes himself up because, according to K. Radvila Perkūnas, a child, who lacks sleep may only spoil his or her health and will never learn anything. The teacher was advised to allow children to play as long as they want. Thus, the nobleman set a goal to Jonušas' Bachelor to fully take care of "his teaching, and even more of his health" (2).

The learning outcomes depended on a particular child. For example, 5-year old future Vilnius palatine Jonušas II Radvila wrote a letter in Polish to his father undoubtedly under supervision of the teacher. At the age of 9 , the child was aware of a big number of facts of ancient history and was able to tell about military campaigns of Alexander Macedon and Caesar. Being 10 years old, he started writing in Latin. The father also developed the revealed artistic skills of the young nobleman. The hobby of Jonušas II Radvila to draw remained through lifelong. The boy's training was not limited only to the school in the manor. At the age of 8 Jonušas II Radvila attended Vilnius Evangelist School, later learnt in schools in Koidanov and Slutsk until, having reached the age of 16, he was sent to study in Europe in 1628 (Wisner, 2000, p. 14-18).

As it has been mentioned, in the middle of the 16th c. - the 17th c. the tradition prevailed that adolescents (14-16 year old) were sent to study in Western European universities (mainly in Italy and Germany). The Academy of Vilnius established in 1579 started to outweigh the importance of foreign universities for the upper nobility. At the end of the 16th c. - the middle of the 17th c., one third of students consisted of Lithuanians and Lowlanders, whereas the rest of them were Ruthenians or students from Livonia, Prussia and Poland. Studies in universities finalised the process of childhood socialisation of the children of nobility and upper nobility. 


\section{Conclusions}

1. Problems of child's socialisation, his or her introduction into society, themes of child and childhood in general in the period of GDL are insufficiently reflected in historiography. Polish historians take leading roles in research on history of GDL children.

2. Available historical sources allow to more exhaustively reveal tendencies in children's upbringing starting with the 16th c. - the middle of the 17th c. and only about children of upper nobility of GDL. Issues of upbringing of children from other social strata are hardly reflected in the accessible GDL sources of the analysed period.

3. The models applied upbringing children of the upper nobility of GDL in the 16th c. - the middle of the 17th c. were determined by individual factors such as social status of a family, child's gender and his/her age and religious affiliation. Following of European model of elite children education may be seen as one of more general factors characteristic of the upper nobility of GDL.

4. During the early socialisation (up to 7 years) boys and girls were brought up together. However understanding of different gender functions in society was formed by different toys and games. The biggest responsibility in upbringing of children was assumed by the mother. The main attention should be directed towards religious education and health care, physical activity was encouraged, linguistic and hygiene skills of children were also formed. The rod was the main means of upbringing.

5. Clear division between boys and girls is observed in socialisation of elder children. Different objectives were set for boys and girls on the basis of the social roles in society of that time. Upbringing of boys was in the domain of noble fathers. They selected teachers and drew up learning plans of their sons. The content of teaching in separate families varied.

\section{Resources}

1. 25 January, 1599, Stakliškès, K. Dieržkas to Radvila Perkūnas, Archiwum Glówne Akt Dawnych w Warszawie, Archiwum Radziwiłlów (hereinafter - AR). dz. V, No. 3515 , No. 9.

2. 1587 VI 29, Orlia, K. Radvila Perkūnas to J. Radvila’s Bachelor Lukui Bednarskiui, “ <...> Którego nigdy dlużay nie ucz, tylko godzin dwie przed obiadom, a po obiedzie godzinę, żeby chęcia niemelankolizowało, a rano go nigdy nie budz, asz się sam ocznie, bo barzo bych ci nie był, za to powinien chociasz bych mi go nie wiem czego nauczył kiedy bys mu niedosypianiem zdrowie popsował. <...> Wszakze iednak o nauke iego, a tym więcej o zdrowiu pilney $<\ldots$. pieczą zebych ci za to 
dziekować miał“, Российская Национальная Библиотека в Санкт Петербурге, f. 971, op. 2, kol aut. 234, No. 119.

3. 31 December 1602, Z. Radvilienè to her husband J. Radvila, "Pisałabym z serca rada do Jej Mci ręką swam, ale Bóg wie, nie tilko kartki ale y jedny litery nie umiem napisać, bo tak beła wola jej msci pani matki moy abym do tych czasów na xziąszkach tilko trochę czytać umiała <...> a tesz pewnie bym beła tak umieiętna żebym umiała pisać do wm mego msciwego pana wołałabym to sama odprawić $<\ldots>$ tedy ten sam wszystek czas na tym trawić będę abym sie uczeła pisać”, Biblioteka Narodowa, Warszawa, rkp. 4838.

4. 1606-1611 m. J. K. Chodkevičiaus laiškai žmonai, Biblioteka Czartotyskich, No. 3915.

5. 1583-1585 m. K. Radvilienès laiškai vyrui K. Radvilai Perkūnui, Biblioteka Narodowa Warszawa, rkp. 4838.

6. 1620 VIII 05, Poločanai, K. Goraiska - K. II Radvilai, Biblioteka Narodowa, Warszawa, rkp. 4838.

7. 1667 II 28, Karaliaučius, B. Radvila - ekonomams, AR, dz. IV, kop. 69.

8. 1607 XII 12, Rožana, L. Sapiega - J. Radvilai, Sapiegienès laiškai vyrui, Archiwum domu Sapiehów, Vol. 1: Listy z lat 1575-1606, opr. A. Prochaska, Lwów, 1892.

9. $A R, \mathrm{dz}$. XI, No. 22;

10. Lietuvos mokslų akademijos Vrublevskių biblioteka, Rankraščiu skyrius, f. 16, No. 9.

11. Lietuvos mokslų akademijos Vrublevskių biblioteka, Rankraščiu skyrius, f. 43, No. 17180.

\section{References}

Acta Tomicina epistole, legationes, responsa, actiones, res geste Sigismundi I Regis Poloniae 1519-1521. (1855). Poznań, 5.

Augustyniak, U. (1999). The upbringing of the young Radziwill's in the 17th c., Acta Poloniae Historica, No. 79, 63-83.

Blaževičius, P. (2011). Seniausieji Lietuvos žaislai. Vilnius: Nacionalinis muziejus LDK valdovų rūmai.

Bogucka, M. (2009). Polski renesans a rodzina: poglądy Mikołaja Reja na małżeństwo i rodzinę, Społeczeństwo Staropolskie. Seria nowa, Vol. III: Społeczeństwo a rodzina, ed. I. M. DackaGórzyńska, A. Karpiński, Warszawa: DiG, 16-20.

Chachaj, M. (1995), Zagraniczna edukacja Radziwiłłów od połowy XVI do połowy XVII wieku, Lublin: Wydawn. Uniwersytetu Marii Curie-Skłodowskiej.

Classen, A. (2005), Philippe Aries and the Consequences. History of Childhood, Family Relations, and Personal Emotions. Where do we stand today? Childhood in the Middle Ages and the 
Renaissance: the results of a paradigm shift in the history of mentality. Ed. A. Classen. Walter de Gruyter.

Dawne i współczesne zabawki dziecięce. (2010). Red. K. Kabacińska, D. Żołądź-Strzelczyk, Poznań-Kielce.

Giddens, A. (2005). Sociologija, Vilnius: Poligrafija ir informatika.

Grzegorz z Żarnowca. (1580). Postylla albo wykłady ewanieliej niedzielnych i na święta <...>, cz. 1, Kraków, Postylle część wtora... Postylle krześciańskiej część trzecia, Kraków 1582, drukarnia M. Wirzbięta.

Gudavičius, E. (1994). Mokyklų atsiradimas Lietuvoje. Žinių ir mokymo lygis. Viduriniojo mokslo susiklostymas. Vilniaus universiteto istorija, 1579-1994, Vilnius: Valstybinis leidybos centras, 17-32.

Jankowski, Cz. (1898). Powiat Oszmiański, S. Petersburg, 2.

Jarczykowa, M. (1995), Krzysztof II Radziwiłł (1585-1640) wobec zagadnień dydaktycznych i naukowych. Studia Bibliologiczne, Katowice, 9, s. 59-70.

Kabacińska-Łuczak, K. (2007). Zabawy i zabawki dziecięce w osiemnastowiecznej Polsce. Poznań, Wydawnictwo Poznańskie.

Karčiauskienė, M., Lukšienė, M., Žukauskas, K., Gučas, A., Laužikas, J., Ročka, M., Šidlauskas, A., Lukšaitė, I., Jurginis, J., Enzinas A., Gudavičius E., Nausėdas V., Kulikauskienẻ R. (1983). Lietuvos mokyklos ir pedagoginés minties istorijos bruožai. Vilnius: Mokslas.

Kiaupa, Z. (1998). Kauno mokyklos XVI amžiuje. Kauno istorijos metraštis. Kaunas: VDU leidykla, 25-35.

Kochanowski, J. (2001). Treny, opr. J. Pelc, Wrocław, 2001.

Kowalczyk, J. (2002). Wychowanie hetmanica Tomasza Zamoyskiego w świetle wydatków z lat 1605-1608. Od narodzin do wieku dojrzałego..., 115-128.

Lewińska, T. (1995). Kolorowy świat zabawek. Zabawki ludowe w Polsce, Kielce.

Lietuvos mokykla ir pedagoginé mintis XIII-XVII a. (1994). Istorijos šaltinių antologija, parengè K. Grigas, V. Kryževičius, I. Lukšaitè. Vilnius: Mokslo ir enciklopedijų leidykla.

Lietuvos pedagoginès minties raida XVI-XVII a. kultūros veikèju raštuose. (1991). Parengé I. Lukšaitè. Vilnius: Šviesa.

Lukšaitè, I. (1991). Aaronas Aleksandras Olizarovijus. Švietimas - valstybės galia. Lietuvos pedagogines minties raida XVI-XVII a., 68-78.

Lukšaitè, I. (1999). Reformacija Lietuvos Didžiojoje Kunigaikštystėje ir Mažojoje Lietuvoje. XVI a. trečias dešimtmetis - XVII a. pirmas dešimtmetis, [Vilnius]: Baltos lankos.

Mastianica, O. (2012). Praverus namų duris: moteru švietimas Lietuvoje XVIII a. pabaigoje XX a. pradžioje. Vilnius: Lietuvos istorijos instituto leidykla.

Matušakaitė, M. (2003). Apranga XVI-XVIII a. Lietuvoje. Vilnius: Aidai.

Ochamnskis, J. (1996). Seniausios Lietuvos mokyklos XIV a. pabaigoje - XVI a. viduryje. Senoji Lietuva. Vilnius: Mintis.

Ochmański, J. (1972). Biskupstwo wileńskie w średniowieczu. Ustrój i uposażenie, Poznań: UAM. 
Od narodzin do wieku dojrzałego. Dzieci i młodziez w Polsce (2002), Cz. I: Od średniowiecza do wieku XVIII, po red. M. Dąbrowskiej, A. Klondera, Warszawa: Instytut Archeologii i Etnologii PAN, 2002.

Olizarovijus, A. A. (2003). Apie politinę žmonių sąungą. Translated by J. Sarcevičienè. Vilnius: Aidai.

Pacevičius, A. (2001). Mokyklos. Lietuvos Didžiosios Kunigaikštijos kultūra. [Vilnius] Aidai, 378-396.

Pliuraitė-Andrejevienė, N. (2012). Lietuvos vaikų žaislai. Vilnius: Versus aureus.

Račkauskas, J. (1994). Švietimo reforma Lenkijoje ir Lietuvoje XVIII a. Vilnius: Mokslo ir enciklopedijų leidykla.

Ragauskienè, R. (1999). Barbora Radvilaitè. Vilnius: Vaga.

Ragauskienè, R. (2002). Lietuvos Didžiosios Kunigaikštystės kancleris Mikalojus Radvila Rudasis (apie 1515-1584 m.). Vilnius: Valstybės žinios.

Ragauskienè, R., Ragauskas, A. (2002). Barboros Radvilaitès laiškai Žygimantui Augustui ir kitiems. Studija apie XVI a. Lietuvos Didžiosios Kunigaikštystės moterų korespondenciją. Vilnius: Vaga. Ragauskienè, R. (2003), The Noblewoman's Court in the Sixteenth-century Grand Duchy of Lithuania. Lithuanian Historical Studies, 8, 24-58.

Saar-Kozlowska, A. (2003). Princess Anna Vasa. An extraordinary woman in Swedish and Polish history. The Vasa Dynasty and the Baltic Region. Politics, Religion and Culture 1560-1660, Kalmar, 39-50.

Sarcevičienè, J. (2003). Vaikas XVI-XVII a. LDK visuomenejje: galimi auklejjimo ir socializacijos modeliai. Menotyra, 2, 4-10.

Sokolowski, W. (1989). Instrukcja pedagogiczna dla Janusza Radziwiłła do szkoły zborowej w Wilnie (kartka z dziejów wychowania młodzieży szlacheckiej na Litwie w XVII w.). Rozprawy $z$ dziejow Oswiaty, 32, 261-273.

Urban, W. (1986). Podpisy małopolskich intelektualistów XVI-XVII w. Biuletyn Biblioteki Jagiellońskiej, 36, 70-85.

Vyskupo Ignoto Jokūbo Masalskio Kauno dekanato vizitacija 1782 m. (2001) par. V. Jogèla. Vilnius: Katalikų akademija.

Wisner, H. (2000). Janusz Radziwiłł 1612-1655. Wojewoda Wileński, Hetman Wielki Litewski, Warszawa.

Wisner, H. (1969). Lata szkolne Janusza Radziwiłłla. Przyczynek do dziejów szkolnictwa kalwińskiego na Litwie w pierwszej połowie XVII wieku. Odrodzenie i Reformacja w Polsce, 14, 183-194.

Zachara, M., Majewska-Lancholz, T. (1971). Instrukcja Krzysztofa II Radziwiłła dla syna Janusza, Odrodzenie i Reformacja w Polsce, 16, 171-184.

Żołądź-Strzelczyk, D. (2002). Dziecko w dawnej Polsce, Poznań: Wydawnictwo Poznańskie. Żołądź-Strzelczyk, D. (2012). In Codzienność dziecięca opisana słowem i obrazem. Życie dziecka na ziemiach polskich od XVI do XVIII wieku. K. Kabacińska-Łuczak. Warszawa: DiG. Скеп'ян, А. А. (2013). Князі Слуцкія. Мінск. 


\title{
Lietuvos Didžiosios Kunigaikštystès diduomenès vaikų auklèjimo modeliai XVI-XVII a. viduryje
}

\author{
Raimonda Ragauskienè \\ Lietuvos edukologijos universitetas, Istorijos fakultetas, Lietuvos istorijos katedra, \\ T. Ševčenkos g. 31, 03111 Vilnius, raimonda.ragauskiene@leu.lt
}

\section{Santrauka}

Vaiko socializacijos, jo įvedimo į visuomenę, kaip ir apskritai vaiko bei vaikystės, Lietuvos Didžiosios Kunigaikštystès (LDK) laikotarpiu tematikai istoriografijoje skiriama nepakankamai dèmesio. Nemažai LDK vaikų istorijos tyrimų atliko lenkų istorikai. Išlikę istoriniai šaltiniai leidžia detaliau atskleisti vaikų auklëjimo tendencijas, pradedant nuo XVI-XVII a. vid. ir tik apie LDK diduomenès vaikus. Kitų socialinių grupių vaikų auklëjimo klausimai menkai atsispindi išlikusiuose minèto laikotarpio LDK šaltiniuose.

XVI-XVII a. vid. LDK didikų vaikų auklejimo modelius lèmè individualūs faktoriai, tokie kaip šeimos padètis visuomenèje, vaiko lytis ir jo amžius, religinė priklausomybè. Tarp bendresnių diduomenei būdingų veiksnių pažymėtinas sekimas europietišku elito vaikų lavinimo modeliu.

Nors berniuko gimimas diduomenès šeimai buvo daug naudingesnis ir turto, ir giminès pratęsimo požiūriu, abiejų lyčiu vaikų gimimas tose šeimose buvo sutinkamas vienodai džiaugsmingai. Taip pat vienodai tèvai sielojosi ir dèl visų anksti mirusių savo vaikų. Diduomenès vaikų ankstyvosios socializacijos laikotarpiu (iki 7 metų) pagrindinès pareigos ịvesdinant vaikus ị visuomenę teko motinoms. Jos skyrè labai daug dèmesio savo vaikams ir jų priežiūrai. Vaikui anksti tapus našlaičiu, motinos pareigas perimdavo tèvo paskirti dvariškiai (auklès, dvaro pareigūnai ir kt.). Tèvai savo ruožtu taip pat domèjosi vaikų gyvenimu.

Ankstyvajame vaikų amžiuje berniukai ir mergaitės buvo auklejami kartu. Kartu pastebimas auklejimo modelių išsiskyrimas, minètu amžiaus tarpsniu pasireiškęs daugiausia per vaikams duodamus skirtingas lyčių funkcijas visuomenejje įprasminančius žaislus ir organizuojant vaikų žaidimus. Daugiausia dèmesio ugdant mažuosius kreipta ’̇ religinị auklejimą, sveikatos priežiūrą, tai suprantant ir kaip fizinio aktyvumo skatinimą, kalbinių ir higienos igūdžių formavimą. Siekiama išugdyti paklusnų vaiką, todèl nesitenkinta vien moralais, pagrindine auklejjimo priemone laikyta rykštè.

Ūgtelejusių vaikų auklejjimas dẻl skirtingo požiūrio ị mergaites ir berniukus ir jų ateities uždavinius visuomeneje skyrèsi. Didikų dukros auklètos tik namuose, čia gaudavo „namų“ išsilavinimą. Mokymo lygis nebuvo žemas. Dalis merginų buvo raštingos, visos buvo puikiai susipažinusios su Šventuoju Raštu, suvokè teisinius dalykus. Dvaruose vyko 
muzikinis ugdymas, mokyta šokti, rankdarbių, kai kuriais atvejais, supažindindavo su vaistiniais augalais. Merginų auklèjimas baigdavosi joms ištekejjus. Sūnų lavinimui diduomenė buvo reiklesnè. Jų socializacija 7-14 (16) m. tarpsniu vyko ir namuose, ir aukštesnèse nei pradinès mokyklose. Tẻvai parengdavo detalias vaikų auklèjimo instrukcijas. Kai kuriais atvejais, kokias mokyklas ir mokytojus parinkti, spręsdavo ne tik tèvai, bet ir motinos, dažniausiai našlès. Berniukai turèjo žinoti religines tiesas (pagal konfesiją), būti raštingi, mokėti kelias kalbas ar turèti jų pradmenis, žinoti reikšmingus istorinius ịvykius, mokèsi ir oratorystès meno. Daug dèmesio skirta fizinei kultūrai, atskirais atvejais buvo ugdomi meniniai sugebėjimai. LDK diduomenė auklejjimo procese stengèsi neapkrauti vaikų pernelyg intensyviu mokymusi, labai rūpinosi gera vaikų sveikata. Studijos universitetuose užbaigdavo diduomenès jaunuolių vaikystės socializacijos procesą.

Esminiai žodžiai: Lietuvos Didžioji Kunigaikštystė (LDK), XVI-XVII a., vaikas, vaikystès socializacija, auklèjimo modeliai, švietimas LDK laikotarpiu. 